\title{
A Model to Assess Lactic Acid Bacteria Aminopeptidase Activities in Parmigiano Reggiano Cheese During Ripening
}

\author{
M. Gatti, ${ }^{, 1,2}$ J. De Dea Lindner, ${ }^{\star 2}$ F. Gardini,† G. Mucchetti,‡ D. Bevacqua,§ M. E. Fornasari,\# and E. Neviani* \\ *Dipartimento di Genetica, Biologia dei Microrganismi, Antropologia, Evoluzione, Università di Parma, Via G. B. Usberti, 11/A, 43100, Parma, Italy \\ †Dipartimento di Scienze degli Alimenti, Università di Bologna, Sede di Cesena, Piazza Goidanich 60, 47023, Cesena, Italy \\ łDipartimento di Ingegneria Industriale, Università di Parma, Via G. B. Usberti, 181/A, 43100, Parma, Italy \\ $\S$ Dipartimento di Scienze Ambientali, Università di Parma, Via G. B. Usberti, 11/A, 43100, Parma, Italy \\ \#Centro di Ricerca per le Produzioni Foraggere e Lattiero-Casearie (CRA-FLC), Via A. Lombardo 11, 2600, Lodi, Italy
}

\section{ABSTRACT}

The aim of this work was to investigate in which phases of ripening of Parmigiano Reggiano cheese lactic acid bacteria aminopeptidases present in cheese extract could be involved in release of free amino acids and to better understand the behavior of these enzymes in physical-chemical conditions that are far from their optimum. In particular, we evaluated 6 different substrates to reproduce broad-specificity aminopeptidase $\mathrm{N}$, broad-specificity aminopeptidase C, glutamyl aminopeptidase A, peptidase with high specificity for leucine and alanine, proline iminopeptidase, and X-prolyl dipeptidyl aminopeptidase activities releasing different $\mathrm{N}$-terminal amino acids. The effects of $\mathrm{pH}, \mathrm{NaCl}$ concentration, and temperature on the enzyme activities of amino acid B-naphthylamide (BNA)-substrates were determined by modulating the variables in 19 different runs of an experimental design, which allowed the building of mathematical models able to assess the effect on aminopeptidases activities over a range of values, obtained with bibliographic data, covering different environmental conditions in different zones of the cheese wheel at different aging times. The aminopeptidases tested in this work were present in cell-free Parmigiano Reggiano cheese extract after a 17-mo ripening and were active when tested in model system. The modeling approach shows that to highlight the individual and interactive effects of chemical-physical variables on enzyme activities, it is helpful to determine the true potential of an aminopeptidase in cheese. Our results evidenced that the 6 different lactic acid bacteria peptidases participate in cheese proteolysis and are induced or inhibited by the cheese production parameters that, in turn, depend on the cheese dimension. Generally, temperature and

Received February 1, 2008.

Accepted May 19, 2008.

${ }^{1}$ Corresponding author: monica.gatti@unipr.it

${ }^{2}$ Monica Gatti and Juliano De Dea Lindner contributed equally to this work.
$\mathrm{pH}$ exerted the more relevant effects on the enzymatic activities, and in many cases, a relevant interactive effect of these variables was observed. Increasing salt concentration slowed down broad-specificity aminopeptidase $\mathrm{C}$, glutamyl aminopeptidase A, proline iminopeptidase, and peptidase with high specificity for leucine and alanine. Interestingly, this variable did not affect broad-specificity aminopeptidase $\mathrm{N}$ and positively affected X-prolyl dipeptidyl aminopeptidase. The models elaborated varying $\mathrm{pH}$, temperatures, and salt concentration and were a useful, low cost, and fast tool to understand the role of the main peptidases in the different phases of cheese ripening in relation to the major environmental factors influencing enzyme activity.

Key words: aminopeptidase activity, lactic acid bacteria, Parmigiano Reggiano cheese, predictive model

\section{INTRODUCTION}

Parmigiano Reggiano (PR) is a typical Italian hard cooked cheese produced from raw partially skimmed milk with the aid of a natural whey starter culture mainly composed of thermophilic lactobacilli such as Lactobacillus helveticus and Lactobacillus delbrueckii ssp. lactis, which largely dominate the bacterial population during the first part of ripening (Mucchetti and Neviani, 2006).

During the aging process, PR milk curd caseins undergo an extensive degradation. This proteolysis occurs in 2 steps. In the first step, peptides are generated through the action of plasmin (Ferranti et al., 1997; Gaiaschi et al., 2000; Considine et al., 2002) and bacterial proteinases (Nielsen, 2002; Caira et al., 2003). In the second step, bacterial aminopeptidases liberate free amino acids (Resmini et al., 1985) and different-sized peptides (Addeo et al., 1992; Fornasari et al., 2003) from the peptides generated in the first one (Gatti et al., 1999, 2004).

It is well known that the total amount of free amino acids increases during ripening of PR (Resmini et al., 
1985) and some aminopeptidase of lactic acid bacteria (LAB) are present and active throughout ripening in Grana Padano, PR (Gatti et al., 1999; Sforza et al., 2004), Emmental (Gagnaire et al., 1998), and Cheddar or Saint Paulin cheeses (Chapot-Chartier et al., 1994; Wilkinson et al., 1994; Crow et al., 1995). However, it is not well known in which phase of the cheese manufacture and ripening these LAB peptidases play their role and how they act in relation to the physicalchemical parameters. In fact, from the initial steps of the cheesemaking up to the end of ripening, changes of the parameters $\mathrm{pH}$, temperature, and $\mathrm{NaCl}$ concentration modify the environment and force the enzymes to act under conditions far from their optimum. Cooking temperature of the curd, slow heat dissipation during lactic acid fermentation, whey drainage from the curd, drop of $\mathrm{pH}$ within the first $24 \mathrm{~h}$ and its slow climb (Pellegrino et al., 1997; Neviani et al., 1998; Mucchetti and Neviani, 2006), and brining and uptake of $\mathrm{NaCl}$ and its slow diffusion into the cheese (Mucchetti and Neviani, 2006) are factors that deeply modify the matrix, regulate growth of microorganisms, induce autolysis, and influence the activities of bacterial peptidases.

Lactobacillus helveticus and L. delbrueckii ssp. lactis harbor aminopeptidases able to cleave different $\mathrm{N}$ terminal amino acids from peptides (Kunji et al., 1996; Savijoki et al., 2006). Peptidase activities are high in cheese where the high number of microorganisms is associated with an extended autolysis (Gatti et al., 1999). The activity of these peptidases is very important during ripening because they supply free amino acids that can be further metabolized with a relevant impact on cheese flavor or can be an important resource for LAB metabolism (Fernandèz and Zuniga, 2006). The amino acid resulting from proteolysis are the major precursor of specific flavors compounds, such as various alcohols, aldehydes, acids, esters, and sulfur compounds (Smit et al., 2005). For example, the branched amino acid leucine is first converted to the correspondent a-ketoacid (a-ketoisocaproate), which can be transformed by oxidative decarboxylation (isovalerate), decarboxylated to aldehydes (3-methylbutanal) and related alcohols (via alcohol dehydrogenase), or reduced to hydroxyacid (2-hydroxyisocaproate).

A typical PR cheese wheel has a diameter of about 44 $\mathrm{cm}$ and is about $20 \mathrm{~cm}$ high. The total weight is around 35 to $38 \mathrm{~kg}$. Given these proportions and the conditions of cheese-making and ripening, the values of $\mathrm{pH}, \mathrm{NaCl}$ concentration, and temperature can markedly vary in relation to the stages of ripening and the zone of the cheese shape. Each of these zones is characterized by variables that can remarkably differ from the other zone during the ripening (Mucchetti and Neviani, 2006).
The aim of this work was to investigate in which stages of ripening of PR cheese, LAB aminopeptidases, liberated after cells autolysis and present in cheese extract, could be involved in secondary casein degradation. In particular, we evaluated 6 different substrates to reproduce PepN, PepC, PepA, PepL, PepI, and PepX activities releasing different $\mathrm{N}$-terminal amino acids.

An experimental design allowed us to obtain a mathematical model able to assess the effect of $\mathrm{NaCl}$ concentration, as well as $\mathrm{pH}$ and temperature on aminopeptidase activities over a range of values covering different environmental conditions in different zones of the cheese wheel at different aging times. This offers a prediction with minimum requirements on experimental data, which makes the approach innovative and faster than direct analyses.

\section{MATERIALS AND METHODS}

\section{Cell-Free Cheese Extract Preparation}

Seventeen-month-ripened PR cheese was kindly supplied by the Consorzio del formaggio Parmigiano-Reggiano (Reggio Emilia, Italy). The wheel was lengthwise cut along the vertical axis, and a central cheese section $10 \mathrm{~cm}$ thick was obtained. A $0.5-\mathrm{cm}$ portion from the cheese crust was obtained and grated with a sterilmixer (Pbi International, Milan, Italy; 11,000 rpm for $10 \mathrm{~s}$ ). Fifteen grams of this grated cheese was homogenized with $50 \mathrm{~mL}$ of $0.05 \mathrm{~mol} / \mathrm{L}$ sodium phosphate buffer, $\mathrm{pH}$ 7.0, with a Stomacher 400 circulator (Pbi International; $230 \mathrm{rpm}$ for $5 \mathrm{~min})$, centrifuged $(12,000 \times \mathrm{g}$ for $10 \mathrm{~min}$ at $4^{\circ} \mathrm{C}$ ), filtered at a $0.22-\mu \mathrm{m}$ pore size using syringe filter units (Sartorius, Firenze, Italy), dialyzed for $24 \mathrm{~h}$ in tube-shaped cellulose (Spectra/por, Spectrum Laboratories Inc., Rancho Dominguez, CA) with a molecular mass cutoff of 3,000 Da, and lyophilized.

Upon use, the lyophilized sample was diluted in the same initial volume of citric buffer $0.05 \mathrm{~mol} / \mathrm{L}$ at 5 different $\mathrm{pH}$ defined for the model system as shown later.

\section{Choice of Parameters and Peptidase Activities}

To describe the phases of ripening of $\mathrm{PR}$ cheese, 5 different values of 3 different parameters $(\mathrm{pH}, \mathrm{NaCl}$ concentration on dry matter in percentage, and temperature) were chosen (Table 1). The choice of these values covered the range of these parameters characterizing the long ripening of $\mathrm{PR}$, the different zone of the wheel, and the possible different environmental condition of aging rooms.

The aminopeptidase activities tested were those able to hydrolyze 6 different substrates: broad-specificity 
Table 1. Experimental design used to test the influence of $\mathrm{pH}, \mathrm{NaCl}$ concentration, and temperature on the selected peptidase activities ${ }^{1}$

\begin{tabular}{|c|c|c|c|c|c|c|c|c|c|}
\hline Run & $\mathrm{pH}$ & $\begin{array}{c}\mathrm{NaCl} \\
(\%)\end{array}$ & $\begin{array}{c}\text { Temperature } \\
\left({ }^{\circ} \mathrm{C}\right)\end{array}$ & \multicolumn{6}{|c|}{ Peptidase } \\
\hline 1 & 5.00 & 6.0 & 12 & 8.70 & 240.50 & 0.38 & 2.02 & 0.41 & 7.02 \\
\hline 3 & 5.25 & 1.5 & 22 & 106.33 & 501.70 & 2.04 & 38.82 & 1.33 & 80.73 \\
\hline 4 & 5.25 & 4.5 & 15 & 49.57 & 352.30 & 1.03 & 16.40 & 0.87 & 32.92 \\
\hline 5 & 5.25 & 4.5 & 22 & 99.97 & 589.40 & 1.73 & 34.23 & 1.15 & 66.73 \\
\hline 9 & 5.75 & 4.5 & 22 & 335.56 & 717.57 & 3.70 & 90.89 & 1.55 & 259.51 \\
\hline 10 & 5.00 & 3.0 & 19 & 28.74 & 354.35 & 0.80 & 13.30 & 0.75 & 23.09 \\
\hline 11 & 6.00 & 3.0 & 19 & 406.85 & 677.48 & 4.01 & 122.96 & 1.59 & 298.25 \\
\hline 12 & 5.50 & 0.0 & 19 & 190.23 & 462.64 & 2.77 & 53.46 & 1.56 & 150.56 \\
\hline 13 & 5.50 & 6.0 & 19 & 141.17 & 556.89 & 2.01 & 43.74 & 0.97 & 96.86 \\
\hline 14 & 5.50 & 3.0 & 12 & 72.28 & 347.07 & 0.77 & 21.38 & 0.69 & 58.03 \\
\hline
\end{tabular}

${ }^{1}$ In the columns on the right are reported the values expressed as arbitrary unit enzymatic activity EA ( $\mu$ mol of B-naphthylamide released per $\mathrm{h}$ per $\mathrm{mL}$ of sample) for every peptidase in each run of the experimental design.

aminopeptidase $\mathrm{N}(\mathbf{P e p N})$ activity was determined using Lys-B-naphthylamide (BNA), broad-specificity aminopeptidase C (PepC) using Arg-6NA, proline iminopeptidase (PepI) activity using Pro-BNA, glutamyl aminopeptidase A (PepA) activity using Glu-BNA, peptidase with high specificity for leucine and alanine (PepL) using Leu-BNA, and activity of the X-prolyl dipeptidyl aminopeptidase (PepX) was determined using Phe-Pro-BNA (Christensen et al., 1999).

\section{Enzyme Assay}

Peptidase activities were assayed by using 0.656 $\mathrm{mol} / \mathrm{L}$ solutions of each 6NA-substrate, prepared as provided by the manufacturer (Bachem Feinchemikalien AG, Bubendorf, Switzerland) in different solutions of sodium phosphate buffer $0.05 \mathrm{~mol} / \mathrm{L} \mathrm{pH}$ defined for the model system without or with the presence of $\mathrm{NaCl}$. Two hundred fifty microliters of the sample and $250 \mu \mathrm{L}$ of BNA-substrate were incubated for different periods, individualized for each amino acid-BNA (Lys-BNA, $4 \mathrm{~h}$; Arg-BNA and Phe-Pro-BNA, 6 h; Leu-BNA, 16 h; ProBNA and Glu-BNA, $30 \mathrm{~h}$ ) at the temperature defined for the model system. The reaction was stopped by adding $250 \mu \mathrm{L}$ of $2.0 \mathrm{~mol} / \mathrm{L} \mathrm{HCl}$. The degree of hydrolysis was determined by measuring the colored product of an azocopulation reaction by reading spectrophotometrically the optical density at $580 \mathrm{~nm}\left(\mathrm{~A}_{580 \mathrm{~nm}}\right)$ according to Bouquien et al. (1988).

Each assay was carried out in duplicate, and average values were calculated. The arbitrary unit of enzyme activity (EA) was defined as the number of micromoles of B-naphthylamide released in $1 \mathrm{~h}$ in $1 \mathrm{~mL}$ of sample.

\section{Modeling of Enzymatic Activities}

The effects of $\mathrm{pH}, \mathrm{NaCl}$ concentration, and temperature on the enzyme activity on 6 different BNAsubstrates were determined by modulating the variables in 17 different runs according to a 3 -factor, 5 -level central composite design (Box et al., 1978). In addition to these 17 combinations, 2 other runs were added to consider favorable (run 19, Table 1) and unfavorable (run 1, Table 1) extreme conditions for the enzyme activity and to amplify the sampling space (Table 1).

Modeling was aimed at describing the enzyme activity as function of the independent variables of the experimental design. A software package (Statistica for Windows, Statsoft, Tulsa, OK) was used to estimate the coefficients of the quadratic polynomial equation regression analysis:

$$
y=B_{0}+\Sigma B_{i} x_{i}+\Sigma B_{i i} x_{i}^{2}+\Sigma B_{i j} x_{i} x_{j}
$$

where $y$ is the dependent variable (peptidase activity); $B_{0}$ is the constant; $B_{i}, B_{i i}$, and $B_{i j}$ are regression coefficients of the model; and $x_{i}$ and $x_{j}$ are the independent variables ( $\mathrm{pH}, \mathrm{NaCl}$ concentration, and temperature). In the final models, variables with significance lower than $95 \%(P<0.05)$ were excluded through a backward stepwise regression. 


\section{RESULTS AND DISCUSSION}

\section{Peptidase Activities}

A variety of proteolytic enzymes released by lysed LAB cells are present in an active form in the cheese, and they contribute, together with the indigenous milk proteinases, to an extensive degradation of cheese casein. The peptidases tested in this work, chosen to evaluate the activities of the free enzymes arising from starter lactic acid bacteria autolysis, were present in cell-free PR extract after a 17-mo ripening and were active when tested in the model system. The PepX was found in many mesophilic and thermophilic LAB, whereas PepN (Savijoki et al., 2006) and PepC were typically associated with $L$. helveticus and $L$. delbrueckii ssp. lactis (Dudley and Steele, 1994; Varmanen et al., 1994; Christensen et al., 1999). The Arg-BNA used to test PepC could also be a measure of a PepS activity present in $S$. thermophilus (Fernandez-Espla and Rul, 1999). The PepL could be representative of L. delbrueckii ssp. lactis activities (Klein et al., 1995; Savijoki et al., 2006). Proline in the N-terminal position is generally hydrolyzed by PepI (Savijoky et al., 2006), and Glu-BNA is the substrate preferably hydrolyzed by glutamyl aminopeptidase PepA purified from S. thermophilus (Rul et al., 1995).

In Table 1 are reported the 6 enzymatic activities, expressed as the number of micromoles of BNA released in $1 \mathrm{~h}$ in $1 \mathrm{~mL}$ of sample, detected in each run of the experimental design. As expected, the conditions defined as worst and better case for the expression of the activities (run 1 and 19, respectively) were characterized by their lesser and greater values. Quantitatively, in favorable conditions the greater activity was PepX, followed by PepC and PepN, which were very similar. The PepL activity was more than 5 times lower than PepX, and PepA and PepI were very low. These data are in agreement with those previously found in PR cheese (Gatti et al., 1999) and in thermophilic Lactobacillus from natural whey starter culture traditionally used for its production (Gatti et al., 2004). In spite of the low activity of PepI and PepA, proline and glutamic acid are free amino acids mainly detected in ripened PR (Careri et al., 1996).

Regarding proline, it is possible to suppose that specialized aminopeptidases, like PepR or PepQ, capable of hydrolyzing proline-containing sequences (Kunji et al., 1996), are important for the degradation of caseinderived peptides because of the high content of proline in these molecules (Mucchetti and Neviani, 2006).

Regarding glutamic acid, it is possible to suppose that its accumulation in the cheese during ripening is due to a lack of further degradation by microbial en- zymes. Moreover, the transformation of glutamic acid in pyroglutamic acid (pGlu) through the activity of a specific cyclase was demonstrated for thermophilic lactic species. The cyclization of glutamic acid in pGlu was proposed by Mucchetti et al. (2000) as a ripening marker in long-ripened cooked cheese.

The conversion of peptides to free amino acids by peptidases is a fundamental metabolic activity in LAB and is crucial during ripening of aged cheese especially when, after the decline of viability of the thermophilic starter culture, cellular autolysis occurs (Gagnaire et al., 1998) and the enzymes are free and active in the cheese even after a long ripening time (Gatti et al., 1999). The availability of such free amino acids is central for cheese flavor formation and its overall characteristics because of the further transformations to which they are subjected. These transformations can also be fundamental for survival and multiplication of bacteria during ripening in an environment characterized by stringent conditions. In fact, it is presumable that bacteria gain energy and regenerate NADH from the degradative pathways of amino acids (Fernandez and Zuniga, 2006).

\section{Modeling of the Peptidase Activities}

The data obtained for each activity in the 19 runs of the experimental design were fitted with a quadratic polynomial equation using a backward stepwise procedure that allowed the simplification of the models by keeping in the final equation only the terms with significance greater than $95 \%(P<0.05)$. The final models obtained are shown in Table 2 . All 3 independent variables were included in at least 1 term of each equation. The models were all highly significant, as demonstrated by the diagnostics reported in Table 2 $\left(\mathrm{R}^{2}\right.$ and $P$-values derived from the $F$-test) and by the relationship between predicted and observed values (data not shown).

To evidence the effects exerted by the 3 variables on the behavior of the enzymatic activities, a first series of graphics was drawn with equations obtained dividing the models by the maximum activity recorded (i.e., the value recorded in run 19). With such transformation, the predicted activities were normalized and varied between 0 (no activity) and 1 (maximum activity observed in run 19). In Figure 1a are reported the normalized influence due to the $\mathrm{pH}$ variation when the other 2 variables were kept constant at their mean values (i.e., temperature $19^{\circ} \mathrm{C}$ and $\mathrm{NaCl} 3 \%$ ). The $\mathrm{pH}$ had a similar influence on PepN, PepC, PepL, and PepA, which increased their activities more than proportionally (due to the presence in the model of the quadratic term with a positive sign) with the diminution of acidity. This 
Table 2. Models obtained for each peptidase activity by fitting the experimental data with a second-order polynomial equation ${ }^{1}$

\begin{tabular}{|c|c|c|c|c|c|c|}
\hline Coefficient & PepC & PepX & PepI & PepL & PepA & PepN \\
\hline $\mathrm{pH}$ & $-1,768.591$ & $2,138.964$ & - & -681.591 & - & $-1,824.740$ \\
\hline $\mathrm{NaCl}$ & $-^{2}$ & 284.280 & - & - & - & - \\
\hline $\mathrm{pH}^{2}$ & 154.353 & -162.696 & - & 63.203 & 0.075 & 145.857 \\
\hline $\mathrm{NaCl}^{2}$ & -0.833 & -5.203 & - & -0.244 & 0.011 & - \\
\hline Temperature $^{2}$ & - & - & - & - & - & - \\
\hline $\mathrm{NaCl} \times \mathrm{Temperature}$ & - & - & - & - & -0.007 & - \\
\hline $\mathrm{R}^{2}$ & 0.991 & 0.997 & 0.980 & 0.993 & 0.967 & 0.992 \\
\hline $\begin{array}{l}\text { F-test } \\
(P \text {-value })\end{array}$ & $\begin{array}{l}382.653 \\
(>0.000001)\end{array}$ & $\begin{array}{l}600.153 \\
(>0.000001)\end{array}$ & $\begin{array}{l}254.831 \\
(>0.000001)\end{array}$ & $\begin{array}{l}369.517 \\
(>0.000001)\end{array}$ & $\begin{array}{l}101.800 \\
(>0.000001)\end{array}$ & $\begin{array}{l}333.234 \\
(>0.000001)\end{array}$ \\
\hline
\end{tabular}

${ }^{1}$ In the final models only the terms with a significance greater than $95 \%(P<0.05)$ were considered, according to a backward stepwise procedure. The $\mathrm{R}^{2}$ and the $F$-test (with the corresponding $P$-value) are also reported.

${ }^{2}$ Coefficient excluded from the model by the stepwise procedure $(P>0.05)$.

increase was approximately linear for PepI, whereas the positive effect of $\mathrm{pH}$ increase on PepX was gradually reduced at the higher values of $\mathrm{pH}$. Increasing the amount of $\mathrm{NaCl}\left(\mathrm{pH} 5.5\right.$ and temperature $\left.19^{\circ} \mathrm{C}\right)$ determined a general linear decrease of all the enzymatic activities considered with the exception of PepC, which was scarcely affected by this variable, and PepX, whose activity was greater at increasing $\mathrm{NaCl}$ percentage, at least until a concentration of about $4 \%$ (Figure $1 \mathrm{~b}$ ).

The effect of temperature (shown in Figure 1c for $\mathrm{pH}$ 5.5 and $\mathrm{NaCl} 3 \%$ ) is similar for all the enzymes, and an almost linear increase of all the enzymatic activities considered was observed when the temperature was augmented from 12 to $25^{\circ} \mathrm{C}$. If, in the winter season, the temperature of the aging rooms decreases, reaching for example $12^{\circ} \mathrm{C}$, hydrolysis would be reduced to $50 \%$. The maintenance of temperature around $18^{\circ} \mathrm{C}$ could be an important compromise to safeguard a good level of enzymatic activity, limit the development of undesirable microorganisms, and obtain a correct cheese exudation. This consideration is in agreement with the $\mathrm{PR}$ rules of production that state that the temperature should not fall below $16^{\circ} \mathrm{C}$ (Rules and Regulation of Parmigiano Reggiano).

The normalization of the enzymatic activity responses indicated that generally they were negatively affected by $\mathrm{pH}$ and temperature decreases, whereas $\mathrm{NaCl}$ concentration increase, within the range of concentration considered here, was favorable only for the dipeptidyl aminopeptidase PepX and negative for all the other peptidases tested. However, the evaluation of the Pareto charts (data not shown) that illustrate the dominant terms in the models affecting the response variables and their statistical significance showed that the interaction $\mathrm{pH} \times$ temperature was the most important in 4 of the 6 models (i.e., PepX, PepN, PepC, and PepI) and particularly in the 3 more active pepti- dases. Temperature and $\mathrm{pH}$ were the most important variables for PepA and PepL, respectively. To better demonstrate the effects of the interactions, the surface responses obtained for PepL and PepX are reported in Figures 2 and 3.

The increase of $\mathrm{NaCl}$ from 0 to $6 \%$ caused a limited reduction of PepL (Figures 2a and 2c). More pronounced are the effects of temperature and $\mathrm{pH}$ and the importance of the interactive effect $\mathrm{pH} \times$ temperature is evident in Figure 2b, which shows that the increase caused by higher $\mathrm{pH}$ values was enhanced by increasing temperature.

Figure 3a shows that PepX activity was favored by $\mathrm{NaCl}$ concentration increment independently of temperature. The same effect could be found also in correspondence with the lowest $\mathrm{pH}$ values; this positive influence decreased with $\mathrm{pH}$ increase and was absent at $\mathrm{pH} 6$ (Figure 3c). Finally, the PepX activity was enhanced by temperature and $\mathrm{pH}$ increases (Figure $3 \mathrm{~b}$ ).

During the ripening of the cheese, $\mathrm{NaCl}$ percentage on dry matter characterizing PR gradually changes because of salt diffusion from the external part to the internal one, reaching a similar value after several months. For this reason, the different zones of the wheel are characterized by different percentages of $\mathrm{NaCl}$ (Mucchetti and Neviani, 2006). It is interesting to note that the $\mathrm{NaCl}$ increase had a different effect on PepX with respect to other aminopeptidases tested. This information may induce the presupposition that the salt works as a cofactor in this hydrolytic reaction important in the cheese ripening.

\section{Enzymatic Activities Prediction}

Enzymatic activities were predicted using the 6 models in 2 different zones of cheese, and namely the external part (corresponding to 2 -cm surface layer un- 

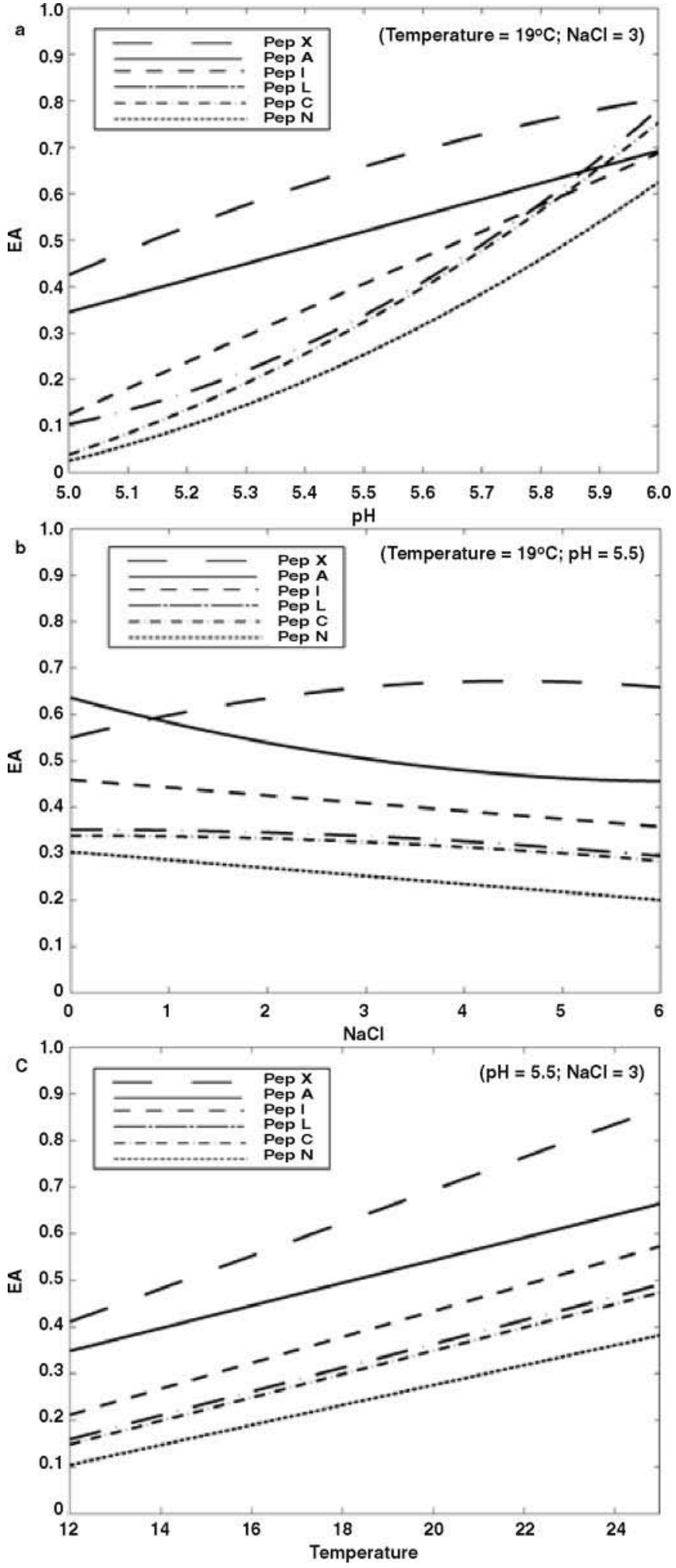

Figure 1. Effect of single environmental variables (a, $\mathrm{pH} ; \mathrm{b}, \mathrm{NaCl}$ concentration; c, temperature) on enzyme activities (EA). Enzyme activities are reported as percentage of the values obtained under most favorable conditions (run 19).

Journal of Dairy Science Vol. 91 No. 11, 2008
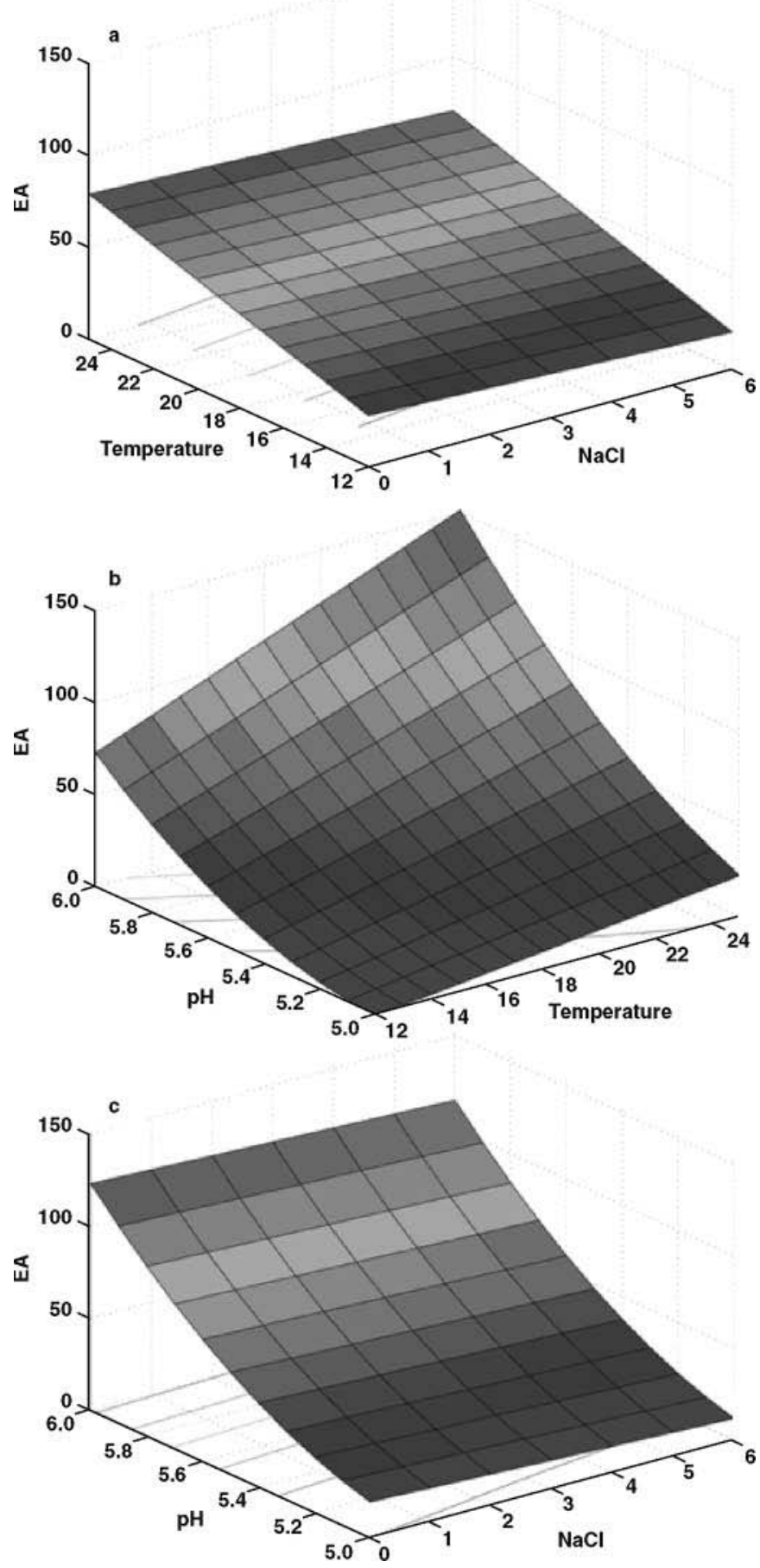

Figure 2. Combined effect of 2 environmental variables (a, temperature and $\mathrm{NaCl}$ concentration; $\mathrm{b}, \mathrm{pH}$ and temperature; $\mathrm{c}, \mathrm{pH}$ and $\mathrm{NaCl}$ concentration) on the PepL enzymatic activity (EA; $\mu$ mol of $B$-naphthylamide released per $\mathrm{h}$ per $\mathrm{mL}$ of sample). The variable not present in each figure is kept constant to its central value (i.e., $\mathrm{pH}$ $5.5, \mathrm{NaCl} 3.0 \%$, temperature $19^{\circ} \mathrm{C}$ ). 
der rind) and the inner part (corresponding to the core of the cheese wheel). These 2 zones were characterized by different $\mathrm{NaCl}$ concentration and $\mathrm{pH}$, whereas the temperature during the ripening is constant in all the cheese wheel, even if variations of its value can be determined by the storage room condition. The prediction of enzymatic activities was carried out considering the values reported in Table 3, which simulated the trend of the independent variables during the ripening after brining period (about $1 \mathrm{mo}$ ) until 12 mo with optimal aging room temperature kept constant at $18^{\circ} \mathrm{C}$. These values have been defined on the basis of literature data (Mucchetti and Neviani 2006) as well as experimental cheese makings carried out at the experimental cheese factory of the Agricultural Research Council, Forage and Dairy Production Research Centre (CRA-FLC, Lodi, Italy; Germano Mucchetti, Department of Industrial Engineering, University of Parma, Italy, personal communication, and Maria Emanuela Fornasari, CRAFLC, Lodi, Italy, personal communication). In general, $\mathrm{NaCl}$ concentration decreases moving toward the inner part of the cheese even if the difference becomes less pronounced during ripening. The $\mathrm{pH}$ is slightly lower in the inner zone, but the difference is reduced (few decimal units) and an increase can be observed during ripening.

Changing in $\mathrm{NaCl}$ concentration and $\mathrm{pH}$ during ripening determined a progressive increase of all the enzymatic activities considered here. However, for 5 peptidase activities (and namely, PepN, PepC, PepA, Pep I, and PepL, the latter shown in Figure 4) the greatest values were always predicted in the inner part of cheese and, in addition, the difference between the external and internal activities throughout all the ripening period remained constant. In contrast, PepX activity was predicted to be greater in the external cheese area (due to its $\mathrm{NaCl}$ content), but the difference between inner and external cheese was reduced during ripening because of a more homogeneous distribution of salt. According to the predictive model obtained, variation in temperature of $2^{\circ} \mathrm{C}$ determined changes in enzyme activities ranging between 10 and 20\% (data not shown).

\section{CONCLUSIONS}

The models obtained allowed the highlighting of individual and interactive effects of chemical-physical variables such as $\mathrm{pH}, \mathrm{NaCl}$ concentration, and temperature on enzyme activities and can be an important tool to determine the true potential of aminopeptidases during cheese ripening. Generally, temperature and $\mathrm{pH}$ exerted the more relevant effects on the enzymatic activities, and in many cases, a relevant interactive
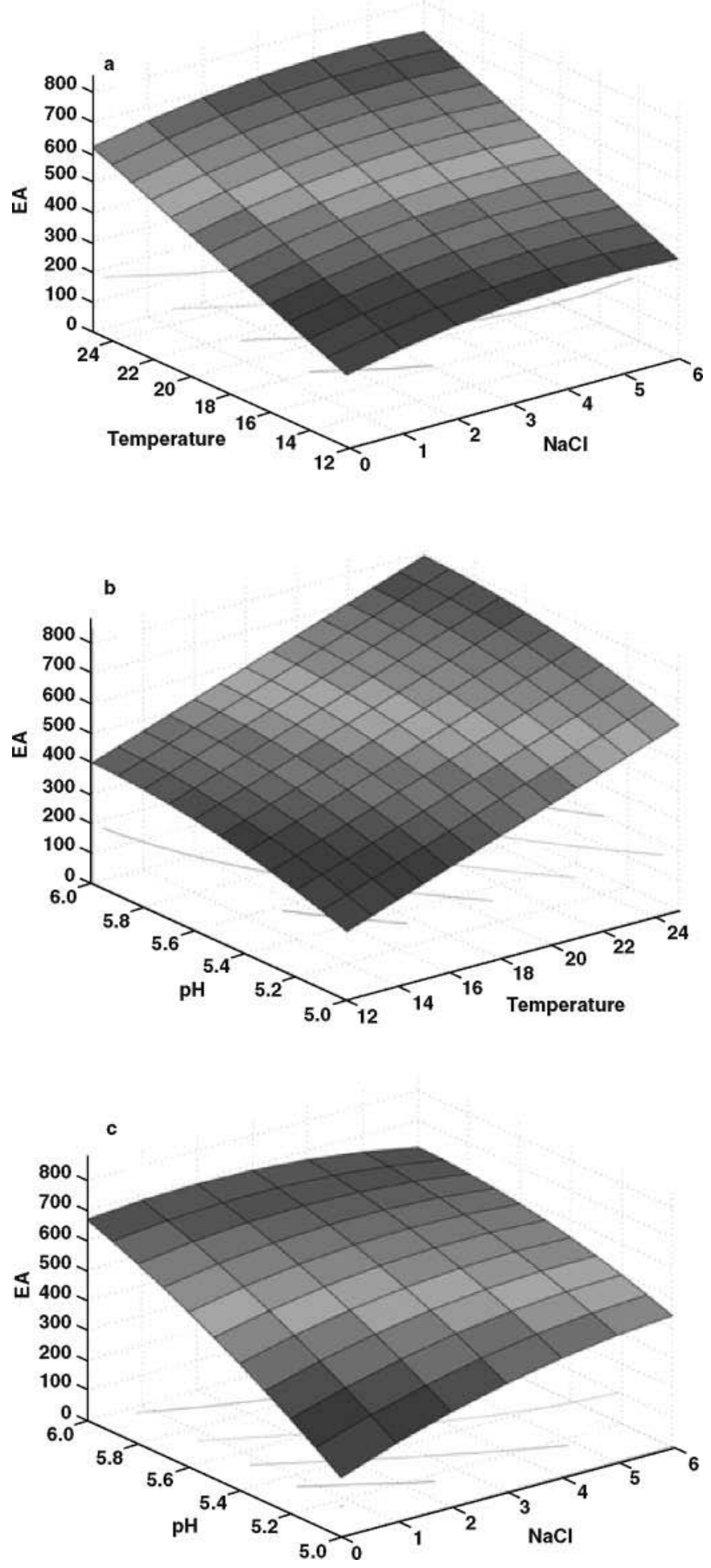

Figure 3. Combined effect of 2 environmental variables (a, temperature and $\mathrm{NaCl}$ concentration; $\mathrm{b}, \mathrm{pH}$ and temperature; $\mathrm{c}, \mathrm{pH}$ and $\mathrm{NaCl}$ concentration) on the PepX enzymatic activity (EA; $\mu$ mol of $B$-naphthylamide released per $\mathrm{h}$ per $\mathrm{mL}$ of sample). The variable not present in each figure is kept constant to its central value (i.e., $\mathrm{pH}$ $5.5, \mathrm{NaCl} 3.0 \%$, temperature $19^{\circ} \mathrm{C}$ ). 


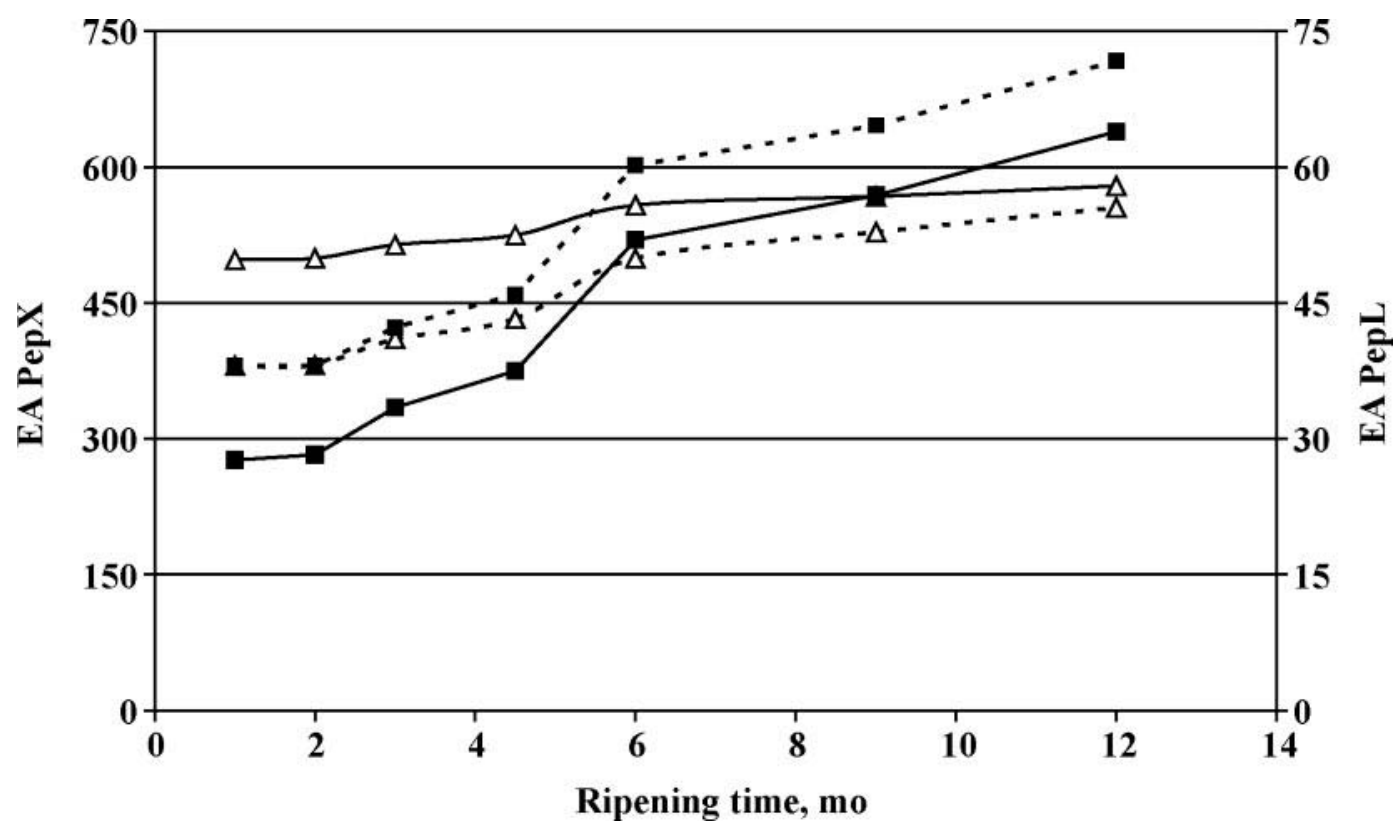

Figure 4. Predicted enzymatic activities of X-prolyl dipeptidyl aminopeptidase (PepX; $\Delta$ ) and peptidase with high specificity for leucine and alanine (PepL; $\mathbf{m})$ in 2 different zones of Parmigiano Reggiano cheese wheel during different steps of the cheese ripening at $18^{\circ} \mathrm{C}$. Dotted line = internal zone; solid line = external zone.

effect of these variables was observed. Increasing salt concentration slowed down PepC, PepA, PepI, and PepL. Interestingly, this variable did not affect PepN and positively affected PepX. Salt tolerance is an important feature for starter LAB enzymes and not starter LAB cheese microflora because high concentrations of $\mathrm{NaCl}$ enter in the whole during the ripening after the brining period.

These results provided evidence that the 6 different LAB peptidases participate in cheese proteolysis and their activity is enhanced or inhibited by the cheese ripening parameters that, in turn, depend on the cheese dimension. Even if the model did not consider the enzyme concentration, which is strictly linked to the microbial development and autolysis, it is a useful, low cost, and fast tool to understand the role of the main peptidases in the different phases of cheese ripening in relation to the major environmental factors influencing enzyme activity.

\section{ACKNOWLEDGMENTS}

This study was funded by the Project "SMEPR Studio e modellazione degli aspetti enzimatici legati alla stagionatura del formaggio Parmigiano-Reggiano" supported by Emilia Romagna Region (LR28/98), Bologna,

Table 3. Values of temperature, $\mathrm{pH}$ and $\mathrm{NaCl}$ concentration (on dry matter) used to predict the enzymatic activities in the external (corresponding to $2-\mathrm{cm}$ surface layer under rind) and internal zone of Parmigiano Reggiano $^{1}$

\begin{tabular}{llcccccc}
\hline & \multicolumn{3}{c}{ External cheese zone } & & \multicolumn{3}{c}{ Internal cheese zone } \\
\cline { 2 - 3 } \cline { 7 - 8 } $\begin{array}{l}\text { Ripening } \\
\text { time }(\mathrm{mo})\end{array}$ & $\mathrm{pH}$ & $\begin{array}{c}\mathrm{NaCl} \\
(\%)\end{array}$ & $\begin{array}{c}\text { Temperature } \\
\left({ }^{\circ} \mathrm{C}\right)\end{array}$ & & $\mathrm{pH}$ & $\begin{array}{c}\text { NaCl } \\
(\%)\end{array}$ & $\begin{array}{c}\text { Temperature } \\
\left({ }^{\circ} \mathrm{C}\right)\end{array}$ \\
\hline 1 & 5.35 & 6.0 & 18 & & 5.37 & 0.07 & 18 \\
2 & 5.35 & 5.8 & 18 & & 5.37 & 0.09 & 18 \\
3 & 5.40 & 5.4 & 18 & & 5.42 & 0.19 & 18 \\
4.5 & 5.44 & 5.2 & 18 & & 5.46 & 0.28 & 18 \\
6 & 5.58 & 5.0 & 18 & & 5.60 & 0.46 & 18 \\
9 & 5.62 & 4.8 & 18 & & 5.64 & 0.87 & 18 \\
12 & 5.68 & 4.8 & 18 & & 5.70 & 1.07 & 18 \\
\hline
\end{tabular}

${ }^{1}$ These values have been defined on the basis of literature data (Mucchetti and Neviani, 2006) as well as Germano Mucchetti, Department of Industrial Engineering, University of Parma, Italy, personal communication, and Maria Emanuela Fornasari, CRA-FLC, Lodi, Italy, personal communication. 
Italy. Authors thank CRPA Spa, Reggio Emilia, Italy, for organizational and technical contribution.

\section{REFERENCES}

Addeo, F., L. Chianese, A. Salzano, R. Sacchi, U. Cappuccio, P. Ferranti, and A. Malori. 1992. Characterization of the $12 \%$ trichloroacetic acid-insoluble oligopeptides of Parmigiano Reggiano cheese. J. Dairy Res. 59:401-411.

Bouquien, C. Y., G. Corrieu, and M. J. Desmazeaud. 1988. Enzymatic methods for determining populations of Streptococcus cremoris AM2 and Leuconostoc lactis CNRZ 1091 in pure and mixed cultures. Appl. Microbiol. Biotechnol. 30:402-407.

Box, G. E. P., W. G. Hunter, and J. S. Hunter. 1978. Statistics for experimenters. Wiley, New York, NY.

Caira, S., P. Ferranti, M. Gatti, M. E. Fornasari, F. Barone, S. Lilla, G. Mucchetti, G. Picariello, L. Chianese, E. Neviani, and F. Addeo. 2003. Synthetic peptides as substrate for assaying the proteolytic activity of Lactobacillus helveticus. J. Dairy Res. 70:315-325.

Careri, M., S. Spagnoli, G. Panari, M. Zannoni, and G. Barbieri. 1996. Chemical parameters of the non-volatile fraction of ripened Parmigiano-Reggiano cheese. Int. Dairy J. 6:147-155.

Chapot-Chartier, M. P., C. Deniel, M. Rousseau, L. Vassal, and J. C. Gripon. 1994. Autolysis of two strains of Lactococcus lactis during cheese ripening. Int. Dairy J. 4:251-269.

Christensen, J. E., E. G. Dudley, J. A. Pederson, and J. L. Steel. 1999. Peptidase and amino acid catabolism in lactic acid bacteria. Antonie Van Leeuwenhoek 76:217-246.

Considine, T., S. Geary, A. L. Kelly, and P. L. H. McSweeney. 2002. Proteolytic specificity of cathepsin $\mathrm{G}$ on bovine $\alpha_{\mathrm{S}_{1}}$ - and B-caseins. Food Chem. 76:59-67.

Crow, V. L., F. G. Martley, T. Coolbear, and S. J. Roundhill. 1995. The influence of phage-assisted lysis of Lactococcus lactis subsp. lactis ML8 on Cheddar cheese ripening. Int. Dairy J. 5:451472.

Dudley, E. G., and J. L. Steele. 1994. Nucleotide sequence and distribution of the pepPN gene from Lactobacillus helveticus CNRZ32. FEMS Microbiol. Lett. 119:41-46.

Fernandez, M., and M. Zuniga. 2006. Amino acid catabolic pathways of lactic acid bacteria. Crit. Rev. Microbiol. 32:155-183.

Fernandez-Espla, M. D., and F. Rul. 1999. PepS from Streptococcus thermophilus. A new member of the aminopeptidase T family of thermophilic bacteria. Eur. J. Biochem. 263:502-510.

Ferranti, P., E. Itolli, F. Barone, A. Malori, G. Garro, P. Laezza, L. Chianese, F. Migliaccio, V. Stingo, and F. Addeo. 1997. Combined high resolution chromatographic techniques (FPLC and HPLC) and mass spectrometry-based identification of peptides and proteins in Grana Padano cheese. Lait 77:683-697.

Fornasari, M. E., M. Gatti, G. Mucchetti, C. Lazzi, F. Gardini, and E. Neviani. 2003. Presenza di attività peptidasiche in formaggio Grana Padano e Parmigiano Reggiano e in lattobacilli termofili isolati dai rispettivi sieroinnesti naturali. Sci. Tec. Latt. Cas. 54:81-93.

Gagnaire, V., S. Lortal, and J. Leonil. 1998. Free active peptidase are detected in Emmental juice extracted before ripening in the warm room. J. Dairy Res. 65:119-128.

Gaiaschi, A., B. Beretta, C. Poiesi, A. Conti, M. G. Giuffrida, C. L. Galli, and P. Restani. 2000. Proteolysis of $\alpha_{\mathrm{S}}$-casein as a marker of Grana Padano cheese ripening. J. Dairy Sci. 83:2733-2739.
Gatti, M., M. E. Fornasari, C. Lazzi, G. Mucchetti, and E. Neviani. 2004. Peptidase activity in various species of dairy thermophilic lactobacilli. J. Appl. Microbiol. 96:223-229.

Gatti, M., M. E. Fornasari, G. Mucchetti, F. Addeo, and E. Neviani. 1999. Presence of peptidase activities in different varieties of cheese. Lett. Appl. Microbiol. 28:368-372.

Klein, J., A. Dick, J. Schick, H. Matern, B. Henrich, and R. Plapp. 1995. Molecular cloning and DANN sequence analysis of pepL, a leucyl aminopeptidase gene from Lactobacillus delbrueckii subsp. lactis DSM7290. Eur. J. Biochem. 228:570-578.

Kunji, E. R. S., I. Mierau, A. Hagting, B. Poolman, and W. N. Konings. 1996. The proteolytic system of lactic acid bacteria. Antonie Van Leeuwenhoek 70:187-221.

Mucchetti, G., F. Locci, M. Gatti, E. Neviani, F. Addeo, A. Dossena, and R. Marchelli. 2000. Pyroglutamic acid in cheese: Presence, origin, and correlation with ripening time of Grana Padano cheese. J. Dairy Sci. 83:659-665.

Mucchetti, G., and E. Neviani. 2006. Microbiologia e tecnologia lattierocasearia. Qualità e sicurezza. Ed Tecniche Nuove, Milan, Italy.

Neviani, E., L. Rossetti, G. Mucchetti, F. Addeo, and G. Giraffa. 1998. Influence of the temperature gradient on the growth of thermophilic lactobacilli used as natural starters in Grana cheese. J. Dairy Sci. 81:31-36.

Nielsen, S. S. 2002. Plasmin system and microbial proteases in milk: Characteristics, roles and relationship. J. Agric. Food Chem. 50:6628-6634.

Pellegrino, L., G. Battelli, P. Resmini, P. Ferranti, F. Barone, and F. Addeo. 1997. Effects of heat load gradient occurring in moulding on characterization and ripening of Grana Padano. Lait 77:217228.

Resmini, P., L. Pellegrino, C. Pazzaglia, and J. A. Hogenboom. 1985. Gli amminoacidi liberi nella tipizzazione del formaggio Parmigiano-Reggiano ed in particolare del prodotto grattuggiato. Sci. Tec. Latt. Cas. 36:557-592.

Rul, F., V. Monnet, and J. C. Gripon. 1995. St-PepA, a Streptococcus thermophilus aminopeptidase with high specificity for acidic residues. Microbiology 141:2281-2287.

Rules and Regulation of Parmigiano Reggiano. Production Standard. http://www.parmigiano-reggiano.it/sotto_sezione/14288/ Production_Standard.aspx Accessed Dec. 15, 2007.

Savijoki, K., H. Ingmer, and P. Varmanen. 2006. Proteolytic system of lactic acid bacteria. Appl. Microbiol. Biotechnol. 71:394-406.

Sforza, S., G. Galaverna, E. Neviani, C. Pinelli, A. Dossena, and R. Marchelli. 2004. Study of the oligopeptide fraction in Grana Padano and Parmigiano-Reggiano cheeses by liquid chromatography electrospray ionization mass spectrometry. Eur. J. Mass Spectrom. (Chichester, Eng.) 10:421-427.

Smit, G., B. A. Smit, and W. J. M. Engels. 2005. Flavour formation by lactic acid bacteria and biochemical flavour profiling of cheese products. FEMS Microbiol. Rev. 29:591-610.

Varmanen, P., E. Vesanto, J. Steele, and A. Palva. 1994 Characterization and expression of the pepN gene encoding a general aminopeptidase from Lactobacillus helveticus. FEMS Microbiol. Lett. 124:315-320.

Wilkinson, M. G., T. P. Guinee, D. M. O'Callaghan, and P. F. Fox. 1994. Autolysis and proteolysis in different strains of starter bacteria during Cheddar cheese ripening. J. Dairy Res. 61:249262. 